\title{
Hypocalcemia after Thyroidectomy for Advanced Local Malignancies
}

\author{
ALEXANDRU GRIGOROVICI ${ }^{1}$, FLORE VARCUS²*, SIMONA MOGOS ${ }^{3}$, ALINA CALIN ${ }^{4}$, DELIA HINGANU5*, \\ MARIUS VALERIU HINGANU5*, CRISTINA PREDA ${ }^{3}$ \\ ${ }^{1}$ Grigore T. Popa University of Medicine and Pharmacy, Faculty of Medicine, I-st Surgical Department, 16 Universitatii Str., 700115, \\ Iasi, Romania \\ ${ }^{2}$ Victor Babes, University of Medicine and Pharmacy, Faculty of Medicine, Timisoara, II-nd Surgical Clinic, 2 Eftimie Murgu Sq., \\ Timisoara,Romania \\ ${ }^{3}$ Grigore T. Popa University of Medicine and Pharmacy, Faculty of Medicine, II-nd Medical Specialties Department, 16 Universitatii \\ Str., 700115, lasi, Romania \\ ${ }^{4}$ St. Spiridon Emergency Clinical Hospital, 4rd Surgery Clinic, 1 Independentei Sq., 700111, Iasi, Romania \\ ${ }^{5}$ Grigore T. Popa University of Medicine and Pharmacy, Faculty of Medicine, I-st Morpho-Functional Sciences Department, \\ 16 Universitatii Str., 700115, lasi, Romania
}

\begin{abstract}
Postoperative hypoparathyroidism is most commonly caused by the extirpation, injury or devascularisation of parathyroid glands. The aim of this study is to establish correlations between the advanced thyroid cancer staging, the appropriate individual treatment, the results obtained, the frequency and intensity of transient and/or permanent post-operative hypocalcemia. The present study can be continued with further researches in order to improve and develop surgical, oncological and endocrine management protocols for patients diagnosed with advanced thyroid cancer and also to avoid these relatively frequent and important complications.
\end{abstract}

Keywords:thyroidectomy, hypocalcemia, parathyroid glands, calcium therapy

Postoperative hypoparathyroidism is most commonly caused by the extirpation, injury or devascularisation of parathyroid glands. It can be considered a medical and surgical emergency [1].

Thyroid cancer is a rare entity among human malign tumors, covering less than $1 \%$ of all cancers, but is the most common endocrine malignancy. The incidence of thyroid cancer in the US is about 7.7 per 100,000 inhabitants / year. Of the histological types, the highest incidence is papillary, 5.7 per 100,000 inhabitants / year, followed by follicular and then medullary form. The incidence of thyroid cancer has increased by about $5 \%$ annually over the past 10 years and the mortality rate has increased from $0.8 \%$ per year from 2002 to 2011 [2, 3].

Women are 3-4 timesmore often affected than men. The effect of Graves disease on the post-operative complications in patients undergoing total thyroidectomy is unclear. This difference may reflect not only real incidence, but also difficult access to medical services and early detection [4].

The staging of thyroid cancer is based on TNM (Tumor, Nodes, Metastases), with a few peculiarities of other cancers. Thus, both the histological diagnosis and the age of the patient are taken into account in the evaluation of the prognosis and the establishment of the therapeutic course. Clinical staging is performed by inspecting and palpating the thyroid gland and regional lymph nodes. Laryngoscopy is also indispensable for highlighting the mobility of vocal cords. Paraclinical examinations include radioactive isotope, ultrasonography, computer tomography and MRI scanning. Diagnosis of thyroid cancer should be confirmed by puncture-needle biopsy or open biopsy. Staging should be completed by a biopsy on suspect lymph node [5-7].

The aim of this study is to establish correlations between the advanced thyroid cancer staging, the choice of individual treatment, the results obtained, the frequency and intensity of transient and/or permanent post-operative hypocalcemia. The results of the study are compared with the data from the literature as well as with the previous experience of the 3rd Surgery Clinic of St. Spiridon lasi Hospital, in order to highlight the causes of these complications. This makes possible to develop surgical, oncological and endocrine management protocols for patients diagnosed with advanced thyroid cancer in order to avoid these relatively frequent and important complications.

\section{Experimental part \\ Materials and methods}

This paper is a retrospective study of 213 cases of thyroid cancer, operated in the 4th Surgery Clinic of the St. Spiridon Emergency Clinical Hospital in lasi between January 2012 and December 2018. In particular, 116 cases diagnosed in advanced stages (III and IV) were analyzed in the Endocrinology Clinic of the St. Spiridon Clinical Hospital.

The data were taken from the table provided by the statistical service of the St. Spiridon Clinical Hospital, as well as from the surgery protocols and histopathological exams. The inclusion criteria in the batch were the primary or secondary diagnosis of malignant thyroid cancer and the over 18 years of age in both genders.

During this period 194 surgical interventions for thyroid cancers were performed. Of these, 145 were performed in female and 49 in male patients, achieving an $\mathrm{M}: \mathrm{W}$ ratio of $1: 2.95$.

\section{Results and discussions}

Most patients were investigated and diagnosed under a prior admission to the Endocrinology Clinic. The evaluation consisted of the general and local clinical examinations, serum levels of thyroid hormones, parathormone and calcium.

* email: varcusflore@yahoo.com; delia_f24@yahoo.com; hanganu.marius@yahoo.com 
The ENT clinical examination and thyroid ultrasonography were also performed.

Indirect laryngoscopy was performed in order to identify possible paralysis of vocal cords, eventual compression or invasion of thyroid nodules. In mostcases, thin needle biopsy puncture and computer tomography were performed. This highlights the anatomical extension of the tumor and the possible invasion of adjacentstructures, thus guiding the extent of surgery.

Percentage of female patients accounted for $74.74 \%$ of all cases, while male patients accounted for $25.25 \%$ (fig. 1) .

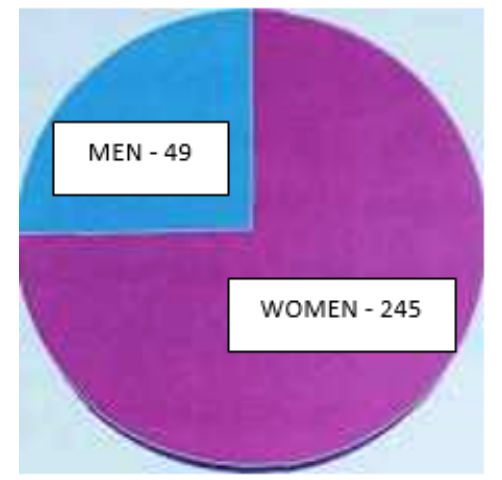

Fig.1. Distribution by gender within the study group

Distribution by age group shows the proportion of the disorder in patients over 50 years of age (fig. 2).

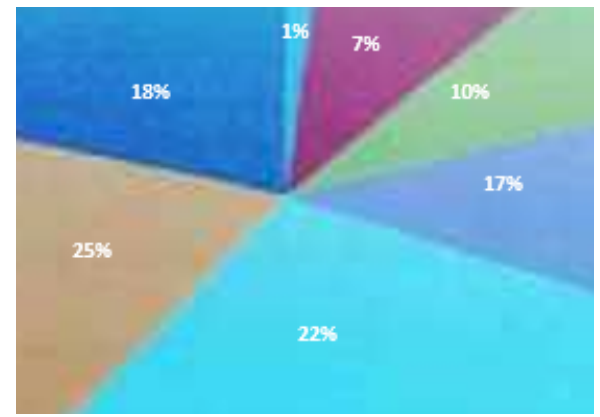

Fig. 2. Percentual distribution of patients by age: $1 \%$ between $18-20,7 \%$ between $21-30,10 \%$ between $31-40,17 \%$ between $41-50,18 \% 71$ and on, $22 \%$ between $51-60$ and $25 \%$ between $61-70$ years old

Thus, out of a total of 194 cases, patients aged 61-70 years are the highest-age group, with 49 cases and $25.52 \%$, followed by the $51-60$ age group , accounting for $22 \%$ of the total cases - 43 patients.

The fourth decade of life includes 33 patients, 31-40 yearold patients are 18 cases, while 18-to 30-year-old patients are 16 cases.

Patients over the age of 71 mark a decrease in incidence after the peak of $61-70$ years, including 35 cases - $18.2 \%$ of the total. The minimum age in the study group is 19 years and the maximum of 84 and a medium age of 55.3 years (fig. 3).

To analyze the distribution of thyroid cancers subtypes among the investigated patients, we took the data from the histopathological bulletins attached to their admission sheets. Of the 194 cases considered, the highest histological weight is papillary thyroid cancer, with $79.89 \%$ of the total cases. This is followed by medullary thyroid cancer with 27 cases, anaplastic thyroid cancer - 17 cases and follicular thyroid cancer -7 cases.

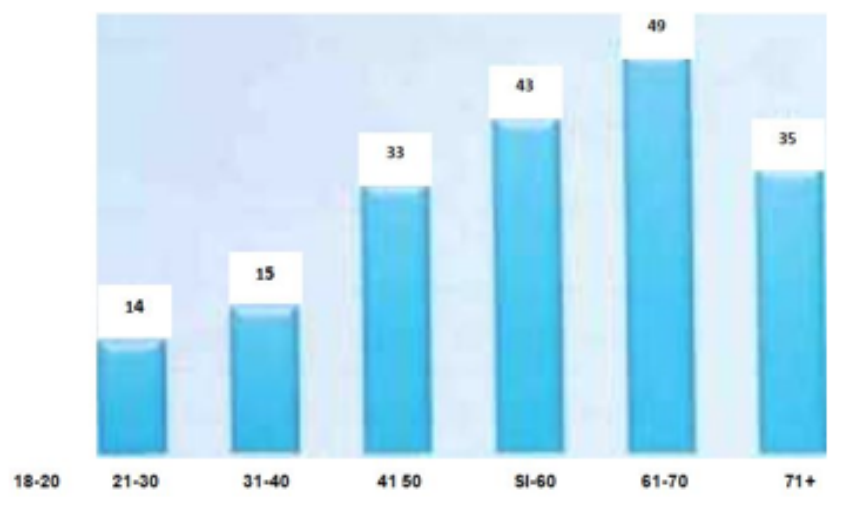

Fig. 3. Patients distribution by age

Three other cases were non-thyroidal cancers: a case of neuroendocrine tumor, a thyroid locomotor plasmocytoma and a renal neoplasm metastasis case.

Analyzing the relationship between the histological subtype and the age for advanced cancers, itcan be observed how the proportion of papillary thyroid cancer decreases from $88.46 \%$ for the age group of $45-50$ years, to $84.61 \%$ for the age group $51-60$ years at $54.05 \%$ for $61-70$ years and only $66.66 \%$ for patients over 70 years of age.

Anaplastic thyroid cancer increases from 0 cases for the 45-50 age group, 2 cases (7.69\%) for 51-60 years, 7 cases for $61-70$ years $(18.9 \%)$ and 7 cases $(25.92 \%)$ for patients aged over 70 years. Follicular thyroid cancer occurs only in the age group of 61-70 years, in a number of 5 cases.

Medullar thyroid cancer is distributed relatively constant between the four age groups: 3 cases (11.5\%) for the age group 45-50 years, 2 cases ( $7.69 \%$ ) corresponding to the 5 th decade of life, 5 cases ( $13.51 \%$ ) for $61-70$ years and 2 cases $(7.4 \%)$ for patients over 70 years of age (fig. 4).

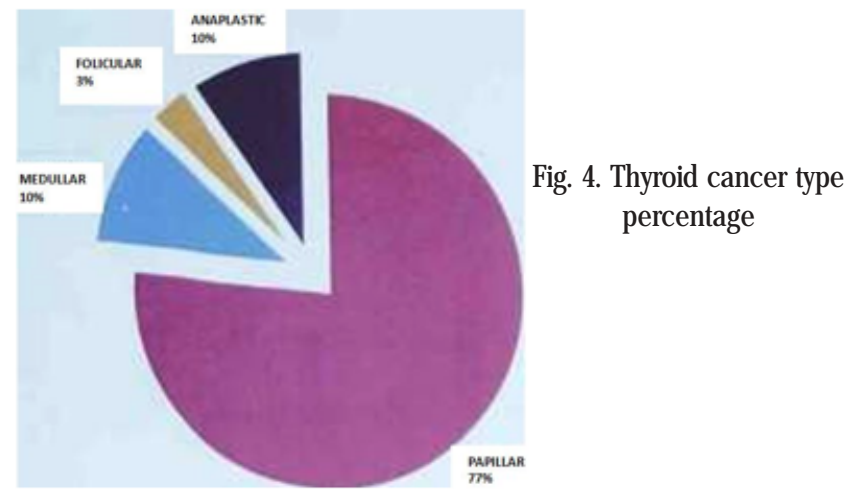

The rate of intraoperative complications related to recurrent laryngeal nerve injury, intraoperative haemorrhage requiring haemostasis and the necessity to achieve a definitive tracheostomy is $13 \%, 17 \%$ and $3.44 \%$, respectively.

Regarding the rate of postoperative complications, these are present in $26.72 \%$ of patients, while the complications strictly related to the operative act are $17.24 \%$. By excluding short-term complications (transient hypocalcaemia and postoperative haemorrhage), it appears that a number of 16 complications were the direct consequence of the operative act. A total of 12 patients (10.34\%) experienced these complications.

Transient hypocalcaemia (16 cases, $29 \%$ of all complications), defined as 6-month remission hypocalcaemia, was associated with complications related to the operative act whereas permanent hypocalcaemia required supplemental calcium 
Table 1

POSTOPERATIVE COMPLICATIONS DEPENDING ON TYPE OF THE INTERVENTION, IN THE CASE OF ADVANCED THYROID CANCERS; $T$ T=TOTAL THYROIDECTOMY, TL=TOTAL LOBISTECTOMY, RD=RADICAL DISSECTION OF THE NECK, SD=SELECTIVE CERVICAL DISSECTION, MRD=MODIFIED CERVICAL RADICAL DISSECTION, ETT=EXTENDED TOTAL THYROIDECTOMY, PTT =PERMANENT TRACHEOSTOMY, TE=TUMOR EXCISION, TOT=THYROIDECTOMY TOTALIZATION

\begin{tabular}{|c|c|c|c|c|c|c|c|c|c|c|c|c|c|c|c|c|}
\hline $\begin{array}{l}\text { Complications } \\
\text { by } \\
\text { intervention }\end{array}$ & TOTAL & $\begin{array}{l}\text { TT+ } \\
\text { SD }\end{array}$ & $\begin{array}{l}\text { TL+ } \\
\text { PTT }\end{array}$ & $\begin{array}{l}\text { ETT+ } \\
\text { RD+ } \\
\text { PTT }\end{array}$ & $\pi$ & $\begin{array}{l}\text { ETT+ } \\
\text { MRD }\end{array}$ & $\begin{array}{l}\text { TT+ } \\
\text { TE }\end{array}$ & TE & WS & $\begin{array}{c}\mathrm{TT}+ \\
\text { MRD }\end{array}$ & $\begin{array}{l}\text { ETT+ } \\
\text { RD }\end{array}$ & $\begin{array}{l}\text { TT+ } \\
\text { RD+ } \\
\text { PTT }\end{array}$ & $\begin{array}{l}\text { TT+ } \\
\text { PTा }\end{array}$ & $\begin{array}{c}\text { TOT+ } \\
\text { RD }\end{array}$ & $\begin{array}{l}\text { TT+ } \\
\text { RD }\end{array}$ & ETT \\
\hline $\begin{array}{l}\text { Oesophageal } \\
\text { fistula }\end{array}$ & 1 & & 1 & & & & & & & & & & & & & \\
\hline $\begin{array}{l}\text { Fistula of the } \\
\text { hypopharynx }\end{array}$ & 1 & & & 1 & & & & & & & & & & & & \\
\hline $\begin{array}{l}\text { Tracheal } \\
\text { fistula }\end{array}$ & $T$ & & & & 1 & & & & & & & & & & & \\
\hline $\begin{array}{l}\text { PERMANENT } \\
\text { HYPOCALCAEMIA }\end{array}$ & 4 & 1 & & & 2 & & & & & & & & & 1 & & \\
\hline $\begin{array}{l}\text { Unilateral } \\
\text { vocal cord } \\
\text { paresis }\end{array}$ & 1 & & & & & 1 & & & & & & & & & & \\
\hline $\begin{array}{l}\text { Paraseptal } \\
\text { emphysema }\end{array}$ & 1 & & & & & & & & & 1 & & & & & & \\
\hline $\begin{array}{l}\text { Phrenic nerve } \\
\text { paralysis }\end{array}$ & 1 & & & & & & & & & 1 & & & & & & \\
\hline $\begin{array}{l}\text { Bilateral vocal } \\
\text { cord paresis }\end{array}$ & 1 & & & & & & & & & & & 1 & & & & \\
\hline $\begin{array}{l}\text { Unilateral } \\
\text { recurrent } \\
\text { nerve paralysis }\end{array}$ & 1 & & & & 1 & & & & & & & & & & & \\
\hline $\begin{array}{l}\text { Pneumomedia } \\
\text { stinum }\end{array}$ & 1 & & & & & & & & & & & & 1 & & & \\
\hline $\begin{array}{l}\text { Subcutaneous } \\
\text { emphysems }\end{array}$ & 1 & & & & & & & & & & & & 1 & & & \\
\hline $\begin{array}{l}\text { TRANSIENT } \\
\text { HYPOCALCAEMIA }\end{array}$ & 16 & 1 & & 1 & 3 & 1 & 2 & & & 2 & 1 & 1 & & & 2 & 2 \\
\hline $\begin{array}{l}\text { Wound } \\
\text { dehiscence }\end{array}$ & 1 & & & & & & & & & & & & & & & \\
\hline $\begin{array}{l}\text { Postoperative } \\
\text { bleeding }\end{array}$ & 2 & & & 1 & & & & & & & 1 & & & & & \\
\hline $\begin{array}{l}\text { Wound } \\
\text { infection }\end{array}$ & 1 & & & & & & & & & & & & & & 1 & \\
\hline
\end{tabular}

medication throughout life ( 4 cases, $7.27 \%$ of total complications)(table 1). This is the consequence of parathyroid gland damage during total thyroidectomy intervention.

The most commonly associated intervention with permanent hypocalcaemia is total thyroidectomy ( 2 cases, $50 \%$ of cases of permanent hypocalcaemia), interventions associated with one case being total thyroidectomy with selective neck dissection and totalization of thyroididectomy with radical dissection of the neck. Transient hypocalcaemia was most commonly associated with simple total thyroidectomy ( 3 out of a total of 16 cases, $18.75 \%$ ).

Two cases were recorded following total thyroidectomy accompanied by tumor excision, unilateral thyroidectomy with radical neck dissection, total thyroidectomies with radically modified dissection of the neck and enlarged total thyroidectomies.

One case was recorded as a consequence of total thyroidectomy with selective dissection, extended thyroidectomy with radically neck dissection and tracheostoma, and total thyroidectomy with radical dissection and definitive tracheostomy.

The predominance of female gender encountered in international and national literature is verified in terms of statistics of the 4th Surgery Clinic in 2012-2018.

REV.CHIM.(Bucharest) $70 \diamond$ No. $3 \diamond 2019$
There are important international studies that highlight the differences in the rate of complications between different centers and operating teams, underlyening the importance of evaluating postoperative complications in the same center over a period of time. This is explained by the direct correlation between the risk of complications and the expertise and experience of the operating team [8-10].

Another study of our research center, between 2000-2002 revealed a complication rate of $6.87 \%$. The studied group comprised all stages, including stages I and II, while the present study examines the complications of Stages III and IV . Also, the percentage of patients that required post-operative reintervention was reported to be $3.17 \%$, while only 2 cases $(1.72 \%)$ were documented in the present study. Permanent hypoparathyroidism was reported in $7.93 \%$ of patients, superior to the $3.44 \%$ found in this group. Considering these aspects, it appears that the experience of the operative team has contributed to the decrease of the rate of postoperative complications.

In a multicenter prospective study focused on the relationship between the rate of postoperative complications (recurrent lesion and hypoparathyroidism) and the experience of the operating team, an association has been found between the experience of the operating team and the surgical 
performance in thyroid cancer surgery, in the sense that the complications were the mostcommon in the case of surgeons at the beginning or, on the contrary, atthe end of their careers. Graves disease significantly increased the risk of transient lesion of the recurrent lacrimal nerve and transient hypoparathyroidism and could be a predictive factor for recurrent postoperative nerve damage and hypoparathyroidism after total thyroidectomy. From this point of view, better results were obtained because of the reducing of their complications rate [11- 15].

Regarding the correlation between surgical intervention and the frequency of postoperative complications, it can be seen that total thyroidectomy with the radical neck dissection and tracheostomy has involved most complications strictly related to the operative act. The patient who underwent this treatment had postoperative hypopharyngeal fistula, transient hypocalcaemia and bleeding, all these requiring reintervention. These complications also correlate with the stage and type of cancer, the patient presenting an IV C grade, thyroid anaplastic carcinoma with a diameter of approximately $15 \mathrm{~cm}$, with right internal jugular vein thrombosis and a right subclavian vein thrombosis and direct invasion of the subhyoid muscles, cervical vessels and recurrent bilateral laryngeal nerve [16-19].

Another type of intervention with multiple postoperative complications was extensive total thyroidectomy with radical neck dissection, in which the patient presented both complications directly related to the operative act and other complications: respiratory insufficiency and acute renal insufficiency. The patient had a fourth-degree papillary cancer with multiple comorbidities.

Routine administration of calcium vitamin D for two weeks was performed in all patients with total thyroidectomy, preventing symptomatic hypocalcaemia. The dose used was $3 g$ per day 3 times a day in the first week and $1.5 \mathrm{~g}$ three times a day in the second week. If symptoms of hypocalcaemia persist, it is recommended to supplement with intravenous calcium gluconate, one ampoule every $12 \mathrm{~h}$, for 7-10 days under the control of serum calcium. Hypoparathyroidism is considered permanent if calcium supplementation is still needed, more than 6 months after surgery. For patients with hoarseness, an indirect laryngoscopy was programmed at 1 , 3 and 6 months postoperatively, respectively, until the vocal cordsfunction. After 6 months recurrent paralysis is considered permanent [20-24].

Depending on the postoperative progression, patients are gusually discharged from the hospital in 2-3 days postoperatively after removing the drainage tube, this being done when the drained liquid does not exceed $25 \mathrm{~mL}$ for three consecutive days. Patients with various postoperative complications had a longer hospitalization period, depending on the complication and the solution to solve it [25,-32].

Follow-up after initial surgery is performed in the Endocrinology Clinic, whrere are done further investigations: a local clinical examination, dosing of serum TSH levels, leukoglobulin or calcitonin, depending on the type of cancer, and cervical ultrasound at 6-12 months, depending on the patient's risk for recurrence. The ultrasound should include the thyroid lodge and the central and lateral lymph nodes. If a positive result (ultrasound ganglia larger than $5 / 8 / 5-8 \mathrm{~cm}$ diameter) is highlighted, itis done a biopsy with a fine needle for cytology with tireglobulin dosing.

\section{Conclusions}

An important post-operative complication of total thyroidectomy is given by hypocalcemia. This one can determin severe symptoms and also increases hospitalization time.The primary cause is secondary hypoparathyroidism following damage to, or devascularisation of, one or more parathyroid glands during surgery. The present study can be continued with further researches in order to improve and develop surgical, oncological and endocrine management protocols for patients diagnosed with advanced thyroid cancerand to to avoid these relatively frequent and important complications.

\section{Referrences}

1.KAZAURE, H.S., SOSA, J.A. ENDOCRINOLOGY AND METABOLISM CLINICS OF NORTH AMERICA, 47, no.4, 2018, p. 783.

2.COOPER, D.S., DOHERTY, G.M., HAUGEN, B.R., KLOOS, R.T., LEE, S.L., MANDEL, S.J., el al. Rvised american thyroid Association Management Guidelines for Adult Patients with Thyroid Nodules and Differentiated Thyroid Cancer. Thyroid, 19, no. 11, 2009, p. 1167-1214. 3.NGUYCN, Q.T., LEE, E.J., HUANG, M.G. PARK, Y.I., KHULLAR A. PLODKOUSKI RA. Am Health Drug Benefits, 8, no.1, 2015, p. 30-40. 4.KWON, H., KIM, J.K., LIM, W., MOON, B.I., PAIK, N.S. Head And Neck-J ournal For The Sciences And Specialties Of The Head And Neck, 41, no.2, 2019, p. 281-285

5.EDGE, S.B., COMPTON, C.C. The American Joint Committee on Cancer: the 7th edition of the AJCC cancer staging manual and the future of TNM. Ann Surg Oncol, 17, no.6, 2010, p.1471.

6.HINGANU, D., HINGANU, M.V., MIHALCEANU, E., CALIN, A.M., PANGAL, A., COSTACHESCU, G., ROMILA, A., Rev. Chim.(Bucharest), 69, no. 3, 2018, p. 714.

7.GATU, A., VELICESCU, C., GRIGOROVICI, A., DANILA, R., MUNTEAN, V., MOGOS, S)., MOGOS, V., VULPOI, C., PREDA, C., BRANISTEANU, D. ACTA ENDOCRINOLOGICA-BUCHAREST, 13, no.4, 2017, p.441.

8.FITZGERALD, P.A. Thyroid cancer. In: Papadakis MA, editor; , McPhee S), editor. , eds. Current Medical Diagnosis \& Treatment 2013. 52nd ed.US: McGraw-Hill Companies; 2013:1126-1134.

9.NIXON, I.J ., GANLY, I., SHAH, J.P. Oral Oncol. 2013; 49: 654-658. 10.BRANDT, F., THVILUM, M., ALMIND, D., CHRISTENSEN, K., GREEN, A., HEGEDÜS, L., BRIX, T.H. PLOS ONE, 8, no.6, 2013, p. e66711 11.DUCLOS, A., PEIX, J.L., COLIN, C., KJAIMPS, J.L., MENEGAUX, F., PATTOU, F. el al. BMJ , 344, 2012, d8041.

12.HINGANU, M.V., HINGANU, D., COZMA, S.R., ASIMIONOAIEISIMIONESCU, C., SCUTARIU, I.A., IONESIE, D.S., HABA, D. Annals of Anatomy, 220, 2018, p. 1.

13.GUO, Z., YU, P., LIU, Z. et al. CLINICAL ENDOCRINOLOGY, 79, no.5, 2013, p.739-746.

14.KISAKOL, G., KAYA, A., GONEN, S., et al. ENDOCRINE JOURNAL, 50, no.6, 2003, p.657-661.

15.TOMA, A.G., SALAHORU P., HINGANU, M.V., HINGANU, D., DIMA COZMA, L. L., PATRASCU, A., GRIGORESCU C. Rev. Chim.(Bucharest), 70, no.1, 2019, p. 143.

16.SITGES-SERRA, A., RUIZ, S., GIRVENT, M. et al. BRITISH J OURNAL OF SURGERY, 97, no.11, 2010, p.1687-1695

17.THOMUSCH, O., MACHENS, A., SEKULLA, C. et al. SURGERY, 133, no.2, 2003, p. 180-185.

18.WEETMAN, A.P., YATEMAN, M.E., EALEY, P.A., et al. JOURNAL OF CLINICAL INVESTIGATION, 86, no.3, 1990, p.723-727

19.SCUTARIU, M.M., HINGANU, D., MACOVEI, G., HINGANU, M.V. ROMANIAN JOURNAL OF ORAL REHABILITATION, 10, no.4, 2018, p.186.

20.SHORE, S., WAGHORN, A.J.W. Thyroidectomy. Surgery (Oxf). 29, 2011, p. 446-450.

21.WILHELM, S.M., WANG, T.S., RUAN, D.T. et al. JAMA SURGERY, 151, no.10, 2016, p. $959-968$

22.RUSU C., PREDA C., SIRETEANU A., VULPOI C. Environmental Engineering and Management J ournal, 14, 2015, p. 913-921. 
23.VASILIU I., PREDA P., SERBAN I., STRUGARU S.A., NICOARA M., PLAVAN G., STOICA B., CIOBANU G., BREDETEAN O., VULPOI, C.Rev Med Chir Soc Med Nat, lasi, 119, N0.4, 2015, p..1037-1044.

24.CUI, Q.X., KONG, D.G., LI, Z.H., WANG, K., ZHANG, D., TANG, J.N., LIAO, X., YUAN, Q.Q., GONG, Y., WU, G.S. TRIALS 20, no.1, 2019, p.96. 25.CHRISTOU, N., MATHONNET, M. J Visc Surg. 150, 2013, p.249-256. 26.HINGANU, M.V., SALAHORU, P., HINGANU, D. Rev Med Chir Soc Med Nat lasi,122, no.3, 2018, p. 522.

27.COZZOLINO, M., GALLIENI, M., CORSI, C.et al. JOURNAL OF NEPHROLOGY, 17, no.1, 2004, p. 3-8.

28.BERGENFELZ, A., JANSSON, S., KRISTOFFERSSON, A. et al. LANGENBECKS ARCHIVES OF SURGERY, 393, no.5, 2008, p. 667-673.
29.BUZDUGA, C.M., GALESANU, C., VULPOI C., PREDA, C., UNGUREANU, M.C., CIOBANU, D., AZOICAI, D., MOGOS, V. Rev Med Chir Soc Med Nat, lasi, 119, no. 1, 2015, p. 45-50.

30.VELICESCU, C., BRANISTEANU, D., GRIGOROVICI, A., GATU, A., PREDA, C., MOGOS, V., DANILA, R. ACTA ENDOCRINOLOGICABUCHAREST, 11, no.4, 2015, p.457-462.

31.GRIGOROVICI, A., COSTACHE, M., VELICESCU, C., SAVIN, G., CIOBANU, D., PREDA, C. CHIRURGIA, 105, no.5, 2010, p. 669-672 32.GRIGOROVICI, A., CHERCIU, M.S., POPESCU, C.M., APOSTOL, D.G.C. , PREDA, C., CALIN, A., AELENEI, P. FARMACIA, 65, no.1, 2017, p.29.

Manuscript received:25.07.2018 